
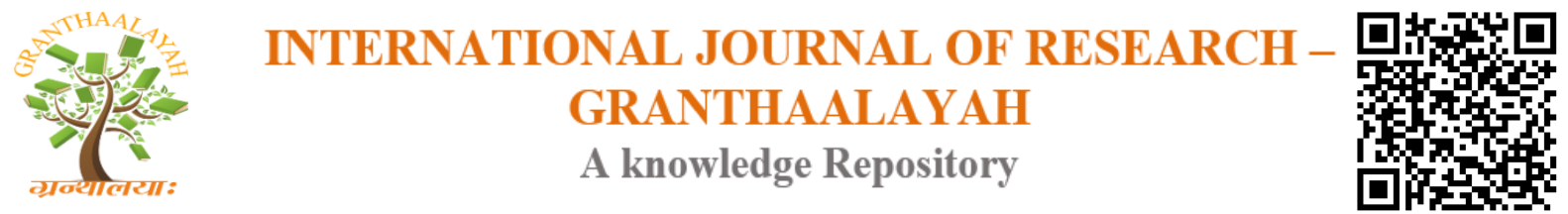

Management

\title{
EFFORT TO INCREASE CATTLE FARMERS CAPACITY IN APPLICATION OF COMPACT ORGANIC FERTILIZER TECHNOLOGY (CASE STUDY ON FARMER GROUP LEMBAH PAMULI NORTH MINAHASA REGENCY)
}

\author{
Eusebius K.M. Endoh ${ }^{* 1}$, Erwin Wantasen ${ }^{* 2}$ \\ ${ }^{*} 1,{ }^{* 2}$ Department of Social Economics, Faculty of Animal Husbandry, Sam Ratulangi University, \\ Manado, Indonesia
}

\begin{abstract}
The aim of the study was to know cattle farmers ability and their characteristics to implement technology of compact organic fertilizer made from cattle manure. The program was conducted in farmers group namely Lembah Pamuli located in Wori sub district regency of North Minahasa. The objects of activity consisted of 15 of cattle farmers whereas the materials included cattle's manure, ureum, probiotic EM4 and other materials that can supported the processing of organic fertilizer production. The approach to the group was extension and training. The result of this program showed that $66.67 \%$ of the participant in extension and training was men and they were 43 years old in averages. Thirty percent of their level of education was elementary school, $40 \%$ in secondary school, $22 \%$ senior high school and $8 \%$ at level of diploma. According to pre and posttest toward members group of Lembah Pamuli in line with their capacity to produce organic fertilizer showed that averages score increase by $47.94 \%$ after they followed the extension and training to produce organic fertilizer. The breeder' knowledge was significantly different $(\mathrm{P}<0.01)$ before and after learning of how to produce organic fertilizer from cattle manure.
\end{abstract}

Keywords: Technology; Organic Fertilizer; Extension; Training.

Cite This Article: Eusebius K.M. Endoh, and Erwin Wantasen. (2017). "EFFORT TO INCREASE CATTLE FARMERS CAPACITY IN APPLICATION OF COMPACT ORGANIC FERTILIZER TECHNOLOGY (CASE STUDY ON FARMER GROUP LEMBAH PAMULI NORTH MINAHASA REGENCY)." International Journal of Research - Granthaalayah, 5(8), 185-190. https://doi.org/10.29121/granthaalayah.v5.i8.2017.2208.

\section{Introduction}

Cattle ranchers are one of the rural development agents who, if empowered, will be able to provide increased productivity in their business that will have an impact on improving the welfare of the farmer's family. The ability of farmers and ranchers in Indonesia in managing their farming system is generally still low due to their knowledge is still limited to what is usually 
done by their families for generations (Hanifa, et al 2013). Therefore, one way that can be done to improve the knowledge and skills of farmers in managing their farming is through counseling and training (Syafaat et al., 1995; Hasibuan, et al, 2013; Baba, 2012).

Beef cattle is one of the mainstay commodities of some farmers in Indonesia, including farmers who have farmers in North Minahasa District. According to data from North Minahasa BPS (2014) the number of cattle in this region in 2013 amount 8,724 head, 3,397 goats, 15,280 pigs, 2,481 ducks, 112,830 poultry, 351,500 broilers and laying hens 73,000. Especially for cattle, Wori sub-district North Minahasa regency is the largest producer with a population of 2,150 heads or $24.64 \%$ of the total population of cattle in North Minahasa District. Cattle are a type of livestock is very popular by people in the village Wori District Wori. Maintenance of cattle in the village of Wori conducted in groups, including one of them is a group of Lembah Pamuli farmers who maintain $40 \mathrm{PO}$ cows. A cattle in a day can produce as much as $10-25 \mathrm{~kg}$ of feces (Prihandini and Purwanto, 2007; Yulisa, 2011). This means that 40 cows owned by the Lembah Pamuli Farmer Group are able to produce $400 \mathrm{~kg}$ - $1000 \mathrm{~kg}$ of cow feces daily or 12 tons to 30 tons of feces each month. The results of Rahmawati (2012) research that from $600 \mathrm{~kg}$ of feces of cattle processed into solid organic fertilizer can generate profit amounting to Rp 589,500 in 14 days. This means that Lembah Pamuli group in Wori Village of North Minahasa Regency has the potential to benefit from the processing of cow feces into compost (organic). Other studies have shown that manure can increase the production and productivity of plants (Masarirambi et al, 2010). Organic fertilizer from cattle as manure has the effect of increasing lamtoro plant production (Hoediati, et al, 1998). Widjayanto, et al (2003) said that the application of organic fertilizer in agricultural areas in Karang Anyar regency can increase rice production from 5.0 ton to 8.3 ton / ha.

From the description above can be seen that organic fertilizer is very prospective if it can be utilized by beef cattle farmers in the village of North Minahasa District Wori. The problem is that members of the Lembah Pamuli cattle business group Wori Village does not have enough knowledge and skills to produce compost fertilizer (solid organic fertilizer) from the cow's feces.

\section{Materials and Methods}

The solution offered to overcome the problems of cattle breeders is the method of implementation of science and technology which consists of instructional methods through the extension activities (FGD) and training activities through technology demonstration followed by the practice of making solid organic fertilizer from cow feces. Counseling about the benefits of solid organic fertilizer from cow dung was done to 15 members of Pamuli Farmer Group Wori Village Wori Subdistrict of North Minahasa Regency with the aim of changing the behavior of group member resources in a better direction (Pambudy, 1999). Some extension philosophy is: (1) counseling relying on the program on the needs of farmers; (2) counseling is essentially a non-formal education process for adults. The goal is to teach farmers, improve their lives by their own efforts, and teach farmers to use their natural resources wisely; And (3) extension workers working with other organizations to develop individuals, groups and nations. The data collected includes the characteristics of Pamuli Lembah Farmer Group members such as age, sex and education level. To know the increase of knowledge and ability of farmers to make solid organic fertilizer from cow feces then do knowledge evaluation before and after gain knowledge from 
counseling and training. Assessment is done through scoring on 20 items questions about the benefits of organic fertilizer from cow dung where each question is worth 1 to 3 . Further data obtained correlation test to determine the relationship of variables before and after cattle ranchers get counseling and knowledge differences from cattle ranchers before and after obtaining counseling by using product moment correlation analysis and paired simple t test (two paired sample t test). Data analysis was performed using SPSS application.

\section{Results and Discussion}

The success of beef cattle business is determined by 3 interrelated elements namely seed, feed and management. Management element plays an important role in the success of cattle business as in the production process and livestock waste (Lantapa, et al, 2015). The success of the business depends on the characteristics of cattle group members. Characteristics of group members are seen from their age and level of education. Members of the group trained for the application of organic fertilizer technology based on cow feces stools amounted to 15 people.

\section{Characteristics of Farmers}

Farmers members of the farmer group Lembah Pamuli Village Wori Kabupoaten North Minahasa as a target of community service activities in this number of 15 people who are entirely livelihood as a farmer also as a cattle rancher. The number of cattle raised every farmer ranges from 1-3 tail because it is still a side business and as a family savings. The types of cows that are kept are ongole peranakan (PO)

The extension activities were conducted by discussion technique to transfer the science team from the team to the target group to solve the problem that was faced related to the business of cow management and the processing of cow waste in the form of cow feces. The characteristics of extension participants are presented in table 1, table 2 and table 3.

Table 1 shows that the majority of counselors are male as many as 10 people or $66.67 \%$ of all participants. This indicates that the activity in the group activities is dominated by men as the head of the family. This condition is an implication of the family decision-making system dominated by the head of the family including the decision to engage in group activities outside the family.

Table 1: Gender of farmer participant of counseling and training

\begin{tabular}{l|l|l}
\hline Gender & Frequently & Percentage (\%) \\
\hline Male & 10 & 66,67 \\
\hline Female & 5 & 33,33 \\
\hline Sum & $\mathbf{1 5}$ & $\mathbf{1 0 0}$ \\
\hline
\end{tabular}

Table 2: Age of farmer paricipant of extensión and training

\begin{tabular}{l|l|l}
\hline Age range & Frequently & Percentage $(\%)$ \\
\hline$<30$ years & 2 & 16 \\
\hline $30-40$ & 3 & 20 \\
\hline $40-50$ & 7 & 44 \\
\hline
\end{tabular}




\begin{tabular}{l|l|l}
\hline $50-60$ & 3 & 20 \\
\hline$>60$ years & 0 & 0 \\
\hline Sum & $\mathbf{1 5}$ & $\mathbf{1 0 0}$ \\
\hline
\end{tabular}

Table 2 shows that $44 \%$ of the aged cattle ranchers are in the range of 40-50 years. Age in the range is included in the productive age category (15-65 years). In the productive age, one will be able to carry out activities including counseling and training of organic solid fertilizer processing from cow feces which is expected to influence the adoption of organic fertilizer technology by cattle farmers of Pamuli Lembah Farmer Group. Increasing the age of the farmers is related to their experience in farming. The more farmers experience the better the management capability of livestock farms.

Table 3 shows that cow breeders' education and counseling education is dominated by secondary education and secondary education with $62 \%$ or 9 students. Meanwhile there are $30 \%$ of primary school-educated and 8\% farmers with diploma education. According to Chamdi (2003) said that the level of education will increase knowledge and skills so that will affect the productivity of business and the success of the farm.

Table 3: Education of farmer participant of extension and training

\begin{tabular}{l|l|l}
\hline Level of school & Frequently & Percentage (\%) \\
\hline Elementary & 5 & 30 \\
\hline Junior & 6 & 40 \\
\hline High & 3 & 22 \\
\hline College & 1 & 8 \\
\hline Sum & $\mathbf{1 5}$ & $\mathbf{1 0 0}$ \\
\hline
\end{tabular}

The level of knowledge of cattle farmers is evaluated prior to counseling and training to find out how far their knowledge level of extension materials and training will be provided. Pre test is done by using 20 items about the technology of making solid organic fertilizer made from cow feces. Pre-test results show that the level of knowledge of oeternak is still quite low with the average score of 35.71 as shown in table 4. After pre-tested the team of devotion to do counseling with processing material of cow feces into solid organic fertilizer using the help of LCD media.

Table 4: Result of Pretest and posttest on participant of extension and training

\begin{tabular}{l|l|l}
\hline Pretest value & Posttest value & Increased value (\%) \\
\hline 35,71 & 52,83 & 47,94 \\
\hline
\end{tabular}

After the counseling participants were provided with knowledge material about the processing of organic fertilizer from cow feces and its benefits for the crop, the participants were given post test with average score to 52.83. This indicates that there has been an increase in knowledge of cattle ranchers who are farmers in Lembah Pamuli group of $47.94 \%$. These results are in line with Hanifa et al (2013) that the knowledge level of cattle ranchers who are members of the Ngudi Mulyo I farmer group in Tasikmadu sub-district Karanganyar increased by 56\% after obtaining information about the processing of farm waste into granule fertilizer. 
Furthermore, by using statistical analysis Paired sample $t$ test to determine whether there is difference of knowledge of cattle farmers before and after given counseling obtained results as in Table 5.

Table 5: The results of paired sample $t$ test and the correlation of variables before and after counseling to the knowledge level of cattle farmers

\begin{tabular}{l|l|l|l|l|l|l|l}
\hline \multirow{2}{*}{ Description } & \multicolumn{5}{|c|}{ Paired differences } & \\
\cline { 2 - 8 } & Avg & Std deviasi & Lower & Upper & $\mathbf{t}$ & df & $\begin{array}{l}\text { Sig } \\
(\mathbf{2} \text { tailed })\end{array}$ \\
\hline $\begin{array}{l}\text { Pre Test - Post } \\
\text { Test , N =15 }\end{array}$ & $-17,2000$ & 5,87002 & $-0,45071$ & $-13,9492$ & $-11,348$ & 14 & .000 \\
\hline Corelation N =15 & & & & & -.092 & & .745 \\
\hline
\end{tabular}

The results of the analysis in Table 5 indicate that the knowledge level of beef cattle farmers after being supplied with the material about the processing of cow feces into different solid organic fertilizer is very real with their knowledge before giving the extension material ( $\mathrm{P}$ $<0,01)$. These results indicate that extension and training activities are very effective to improve the capability of beef cattle farmers who are members of Lembah Pamuli Farmer Group to process cow faeces into solid organic fertilizer. The research results are in line with Widnyana (2011) stating that the extension and advisory efforts of farmer groups are able to increase knowledge, skills and income from organic farming. The result of cow breeder knowledge analysis before and after got knowledge about the processing of cow feces into solid organic fertilizer showed a positive relationship which means counseling and training able to give improvement of cow breeder capability through the increase of knowledge and skill to produce solid organic fertilizer from cow feces, however statistically the relationship is not significant $(\mathrm{P}>0.05)$.

\section{Conclusion}

Extension activities and training on cow dung faecal processing technology into solid organic fertilizer to members of farmer group of beef cattle Lembah Pamuli Wori Village North Minahasa regency able to improve knowledge and skill of farmers equal to $47,94 \%$

\section{References}

[1] Baba, S. 2012. "PARTICIPATION RATE OF DAIRY FARMERS IN EXTENSION AT DISTRICT ENREKANG”. JITP. 2(1): 39-49.

[2] BPS North Minahasa District 2014. "NORTH MINAHASA IN FIGURES 2014". North Minahasa BPS Office Airmadidi Sulut

[3] Chamdi, A.N. 2003. "REVIEW OF SOCIO-ECONOMIC PROFILE OF GOAT BUSINESS IN KRADENAN SUB-DISTRICT GROBOGAN DISTRICT”. Proc. National Seminar on Livestock and Veterinary Technology. Bogor, p 312-317.

[4] Hanifa, A.., R.K. Adi. and E.T. Rahayu.2013. "STRENGTHENING THE SOCIO-ECONOMIC OF BEEF CATTLE FARMERS THROUGH THE ADOPTION OF WASTE PROCESSING TECHNOLOGY OF THE FARMERS, INTO GRANULE FERTILIZER". Proc. National Seminar Towards Civil Society and Sustainable. DPPM Islam Indonesia University. December 18, 2013. ISBN: 978-979-98438-8-3 
[5] Hasibuan. A.M., D. Listyati and B Sudjarmoko. 2013. "PERCEPTION ANALYSIS AND ATTITUDES OF FARMERS ON THE ATTRIBUTES OF COFFEE SEEDS IN LAMPUNG PROVINCE”. Buletin RISTRI 4 (3) : 215-224

[6] Hoediati, D., Sumarsono and D. W. Widjajanto. 1998. "INFLUENCE OF MANURE AND INOCULATION RHIZOBIUM AGAINST REGROWTH OF LAMTORO GUNG (LEUCAENA LEUCOCHEPALA) AFTER FIRST CUT". J. Pastura 2(1) : 1-5.

[7] Lantapa,R., E. Wantasen, M.A.V Manese and F.N.S. Oroh. "ANALYSIS OF BENEFITS OF ORGANIC FERTILIZER BUSINESS IN COMPANY OF CV.AGRONIAGA MANDIRI SUBDISTRICT OF BINTAUNA”. J. Zootek 35(2): 335-339

[8] Masaririmbi. M.T., M.H. Mduduzi, O.T. Olusegun, Oseni and S.E Thokozile. 2010. "EFFECTS OF ORGANIC FERTILIZERS ON GROWTH, YIELD, QUALITY AND SENSORY EVALUATION OF RED LETTUCE (Lactuca sativa L.) 'Veneza Roxa'. Agric. Biol. J. N. Am., 2010, 1(6):1319-1324.

[9] Prihandini P.W, and Purwanto T, 2007. "TECHNICAL GUIDANCE ON MAKING COMPOST MADE FROM COW MANURE". Center for Livestock Research and Development, Pasuruan.

[10] Rahmawati, D.A. 2012. "EFFORTS TO INCREASE FARMERS' INCOME THROUGH THE USE OF ORGANIC FERTILIZER". Faculty of Agriculture Agribusiness Study Program. Brawijaya University. Malang.

[11] Syafaat N, Agustian A, Pranadji T, Ariani M, Setiadjie I, and Wirawan. 1995. "STUDY OF HUMAN RESOURCE STUDIES IN SUPPORTING INTEGRATED PEOPLE'S AGRICULTURAL DEVELOPMENT IN EASTERN INDONESIA. BOGOR”. Research Center for Agriculture Socioeconomics.

[12] Widjajanto, D.W., T. Honmura and N. Miyauchi. 2003. "POSSIBLE UTILIZATION OF WATER HYACINTH (EICHHORNIACRASSIPES (MART.) SOLMS), AN AQUATIC WEED, AS GREEN MANURE IN VEGETABLES CROPPING SYSTEMS”. J. Trop Agric. 47(1):27-33

[13] Widnyana, I.K., 2011. "EFFORTS TO INCREASE FARMER'S INCOME THROUGH THE APPLICATION OF SCIENCE AND TECHNOLOGY IMPROVEMENT OF ORGANIC RICEBASED PRODUCTIVITY”. Science application of Ngayah 2 (2): 35-43

[14] Yulisa M, 2011. "PROFILE OF ORGANIC FERTILIZER BUSINESS". Bhinneka.Kelompok Tani Bhinneka. Subang

*Corresponding author.

E-mail address: eusebiusendoh@ unsrat.ac.id 